\title{
Communication
}

\section{Pecan Propagation: Seed Mass as a Reliable Tool for Seed Selection}

\author{
Tales Poletto ${ }^{1, *(\mathbb{D})}$, Valdir Marcos Stefenon ${ }^{2}{ }^{\mathbb{D}}$, Igor Poletto ${ }^{3}$ and Marlove Fátima Brião Muniz ${ }^{1(\mathbb{C}}$ \\ 1 Department of Plant Defense, Federal University of Santa Maria, Santa Maria 97105-900, Brazil; \\ marlovemuniz@yahoo.com.br \\ 2 Nucleus of Molecular Ecology and Plant Micropropagation, Federal University of the Pampa, Rod. BR290, \\ São Gabriel ZIP 97300-000, Brazil; valdirstefenon@unipampa.edu.br \\ 3 Laboratory of Biological Control and Plant Protection, Federal University of the Pampa, Rod. BR290, \\ São Gabriel ZIP 97300-000, Brazil; igorpoletto@unipampa.edu.br \\ * Correspondence: tecnicotales@hotmail.com; Tel.: +55-55-99922-2060
}

Received: 26 August 2018; Accepted: 6 September 2018; Published: 11 September 2018

\begin{abstract}
Pecan is one of the most important horticultural nut crops in the world. It is a deciduous species native to the temperate zones of North America, introduced into the subtropical regions of Brazil during the 1870s. High quality seedlings are essential to establishing healthy and productive orchards, and selection of seeds is an important factor in this issue. In this study we evaluated the correlation between seed mass, emergence rate and morphometric traits of seedlings in the pecan cultivar Importada. A significant positive correlation $(r>0.81)$ between seed mass and plantlet height, stem diameter, emergence rate and number of leaves was observed. Our results suggest that seed mass can be used as a direct method for seed selection towards production of vigorous pecan seedlings. However, since an increase in seed mass is usually associated with a decrease in the number of seeds that a plant can produce per unit canopy, long-duration studies are recommended in order to evaluate the influence of seed selection on a plantation's production.
\end{abstract}

Keywords: Carya illinoinensis; orchards; seedlings production; emergence rate

\section{Introduction}

The pecan (Carya illinoinensis (Wangenh) K. Koch) is a deciduous tree species of the Junglandaceae family, native to the temperate zones of North America, and one of the most important horticultural nut crops in the world. Pecan is cultivated in a wide range of countries, including USA, Mexico, Israel, South Africa, Australia, Egypt, China, Peru, Argentina, and Brazil [1,2]. Each of these geographic regions places unique environmental constraints on the cultivars that can succeed there. Therefore, pecan producers have to select regionally and horticulturally-adapted cultivars and develop the required technologies for all steps of the production chain, from seed selection for nursery to nut harvesting for the industry. Since high quality seedlings are essential to establishing healthy and productive orchards, studies on new technologies for pecan cultivation in subtropical regions have mostly focused on seedling production [3,4].

Seed sizing is a single technique suggested to be an efficient indicator positively correlated with seed physiological quality and plantlet vigor [5,6]. Adams and Thielges [7] reported a weak positive correlation $(r=0.21)$ between seed size and seedling height in wild C. illinoinensis. In addition, these authors also reported absence of influence of seed weight on germination or seedling vigor in improved North American cultivars of pecan. Although climatic conditions, such as water availability, may interfere in this correlation [5], no study on this topic has been performed for pecan cultivars cultivated under subtropical conditions. 
Given the scarce and inconclusive results concerning the correlation between seed mass and plantlet development in pecan, and the need for regionally adapted cultivars, we conducted a field experiment to examine the correlation between seed mass, plantlet emergence and seedling development of this species under subtropical climatic conditions.

Since the introduction of the pecan in Southern Brazil, farmers have searched for plants more adapted to the climatic conditions of the area, selecting cultivars that allowed the establishment of more healthy and productive orchards. Unpublished studies of our group suggest that the pecan cultivar Importada is one of the most promising for the subtropical climatic conditions of Southern Brazil. Therefore, this study evaluated the correlation between seed mass, seed emergence and plantlet vigor in this cultivar, towards producing healthy seedlings for orchard establishment.

\section{Materials and Methods}

\subsection{Seeds Sampling and Classification}

Seeds of the pecan cultivar Importada were collected from 10 mother-trees in Southern Brazil $\left(28^{\circ} 58^{\prime} 18^{\prime \prime} \mathrm{S}, 52^{\circ} 00^{\prime} 30^{\prime \prime} \mathrm{W}\right.$; grown in a humid subtropical climate without a dry season, a Cfa climate according to the Köppen climate classification), generating a lot of 324 seeds. To overcome dormancy, seeds were maintained within wood boxes in moist sand at $4{ }^{\circ} \mathrm{C} \pm 0.1^{\circ} \mathrm{C}$ for 90 days, following Poletto and collaborators [4]. After this period, seed mass was determined using a precision balance (0.001 $\mathrm{g})$ and seeds were sorted into seven classes according to their mass: Class I: $<4.9 \mathrm{~g}$ (21 seeds); Class II: 5.0-5.9 g (45 seeds); Class III: 6.0-6.9 g (60 seeds); Class IV: 7.0-7.9 g (54 seeds); Class V: 8.0-8.9 g (57 seeds); Class VI: 9.0-9.9 g (54 seeds) and Class VII: >10.0 g (33 seeds).

\subsection{Seeds Sowing and Data Collection}

Seeds were sown manually by placing each seed in a 3-cm-deep hole, with a distance of $50 \mathrm{~cm}$ between rows and $20 \mathrm{~cm}$ between holes. Following the Brazilian System of Soil Classification [8], the soil of the region is Typic Argiudoll. Irrigation was performed through a drip system and weeds were manually controlled. The experiment was conducted using a completely randomized design consisting of 7 to 20 repetitions of three seeds for each seed mass class. The number of repetitions varied across seed mass classes according to the amount of seeds available in each category. Plantlet height $(\mathrm{cm})$, stem diameter $(\mathrm{mm})$, number of leaves and emergence rate ((total of emerged seedlings/total of sown seeds) $\times 100$ ) were evaluated 16 weeks after sowing.

\subsection{Statistical Analysis}

Prior to statistical analysis, data on plantlet emergence were transformed for normalization employing $\sqrt{ }(x+0.5)$. The relationship between seed mass and each measured variable (plantlet height, stem diameter, number of leaves and emergence rate) was evaluated by regression analysis. Differences among seed mass classes were evaluated through the Kruskal-Wallis test, and pairwise comparisons were performed using the Mann-Whitney test with Bonferroni correction. Statistical analyses were implemented using the software PAST 3.02 [8] and Free Statistic Software v1.2.1 [9].

\section{Results}

\subsection{Measures of Plantlet Vigor and Seedling Emergence}

The differences in the measured traits between the smallest seed mass category $(<4.9 \mathrm{~g})$ and the largest seed mass category ( $>10.0 \mathrm{~g}$ ) was 1.35-fold for plantlet height, 1.47-fold for stem diameter, 1.16-fold for leaf number, and 1.85-fold for emergence rate. The mean plantlet height ranged from $24.7 \mathrm{~cm}$ (Class I) to $33.4 \mathrm{~cm}$ (Class VII), the mean stem diameter ranged from $4.6 \mathrm{~mm}$ (Class I) to $6.7 \mathrm{~mm}$ (Class VI), and the mean number of leaves ranged from 11.4 in class I to 13.5 in class VI (Figure 1A-C). The mean emergence rate ranged from $52.4 \%$ in class I to $98.1 \%$ in class VI. Only one replicate in 
Class VI and one in Class VII failed to reach 100\% emergence, while none of the replications in Class I reached $100 \%$ emergence (Figure 1D).
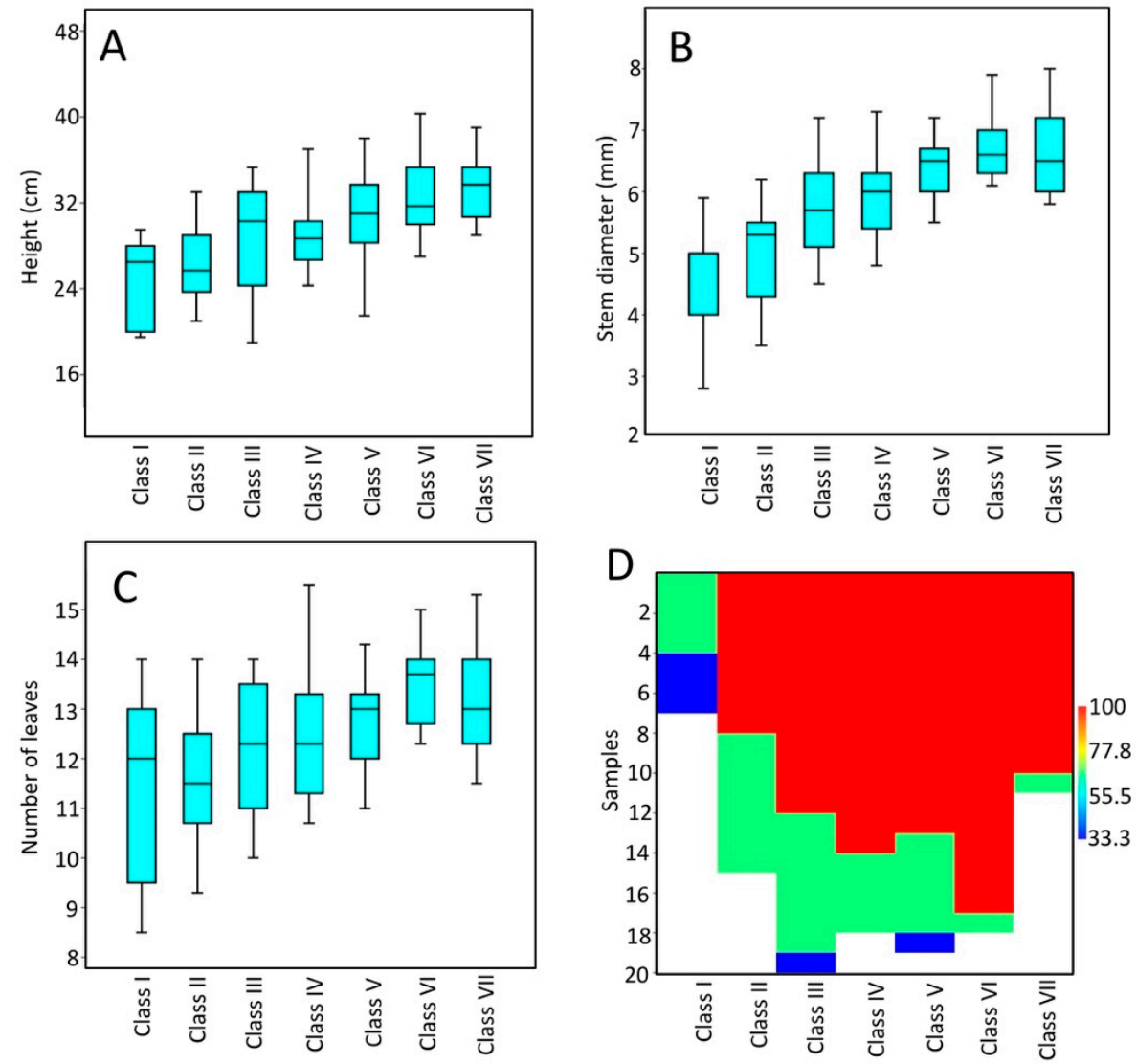

Figure 1. Boxplot diagrams showing the median (bar), 50\% confidence intervals (box) and standard deviation (whiskers) for (A) plantlet height; (B) stem diameter; (C) number of leaves for each seed mass class; and (D) percentage of plantlet emergence determined as the percentage of germinated seeds across replicates for each seed mass class. Note that the number of replicates is different in each class (see text for details).

\subsection{Correlation between Seed Mass, Seedling Emergence and Plantlet Vigor}

A significant positive relationship between seed mass and emergence rate, plantlet height, stem diameter and number of leaves was observed in the regression analyses. Although the correlation between seed mass and the evaluated traits was almost linear, the best fit determined through the coefficient of determination $\left(R^{2}\right)$ was observed using a polynomial model for all correlations (Figure 2).

Accordingly, the Kruskal-Wallis test revealed a statistically significant difference $(P<0.001)$ among seed mass categories for all measured traits, and the pairwise comparisons revealed a clear tendency for significant differences between small seed mass classes and larger seed mass classes (Table 1). Clearly, smaller seeds (Class I) revealed the weakest results and the best results were observed in the largest Classes VI and VII for all traits. The difference between means of classes I and VII were statistically significant for all traits except number of leaves (Table 1). The same pattern occurred when comparing means of Classes I and VI, while means from Classes VI and VII did not differ from each other for any of the traits (Table 1 ). 


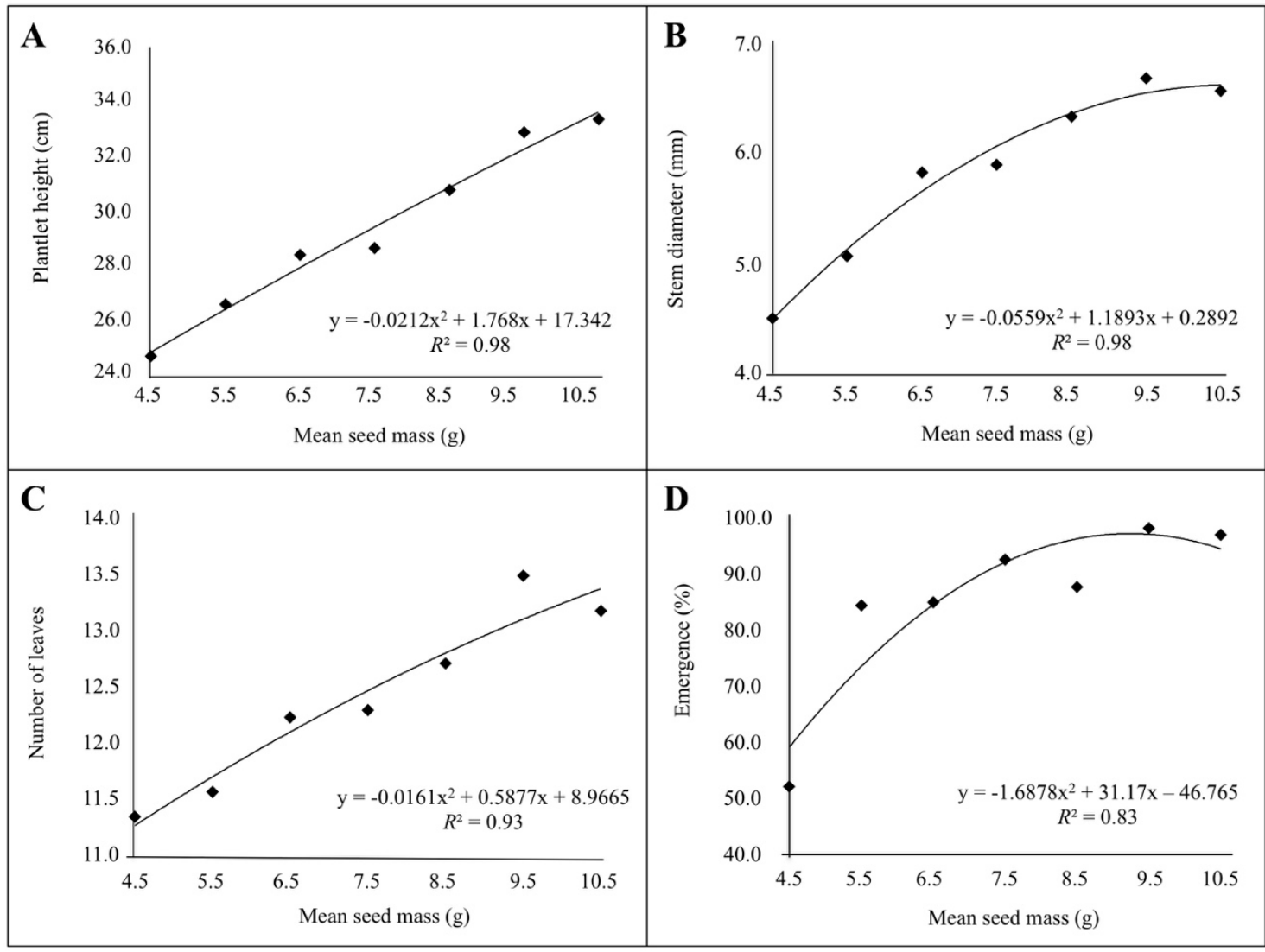

Figure 2. Regression analysis of seed mass of the pecan cv. Importada with means of (A) plantlet height; (B) stem diameter; (C) number of leaves and (D) emergence percentage. Linear regression equations and coefficients of determination $\left(R^{2}\right)$ are presented for the relationships.

Table 1. $P$-values for the pairwise difference between classes for the evaluated traits, based on the Mann-Whitney test with Bonferroni correction. Bold numbers are statistically significant.

\begin{tabular}{|c|c|c|c|c|c|c|c|c|c|c|c|c|c|c|}
\hline Class & & I & II & III & IV & V & VI & Class & I & II & III & IV & $\mathbf{V}$ & VI \\
\hline \multirow{6}{*}{ Height } & II & 1.00 & & & & & & \multirow{6}{*}{$\begin{array}{c}\text { Stem } \\
\text { diameter }\end{array}$} & 1.00 & & & & & \\
\hline & III & 1.00 & 1.00 & & & & & & 0.23 & 0.45 & & & & \\
\hline & IV & 0.71 & 1.00 & 1.00 & & & & & 0.06 & 0.04 & 1.00 & & & \\
\hline & V & 0.09 & 0.09 & 1.00 & 1.00 & & & & 0.01 & 0.00 & 0.63 & 1.00 & & \\
\hline & VI & 0.01 & 0.00 & 0.55 & 0.02 & 1.00 & & & 0.00 & 0.00 & 0.02 & 0.02 & 1.00 & \\
\hline & VII & 0.02 & 0.00 & 0.19 & 0.03 & 1.00 & 1.00 & & 0.02 & 0.00 & 0.27 & 0.72 & 1.00 & 1.00 \\
\hline \multirow{6}{*}{$\begin{array}{c}\text { Number } \\
\text { of } \\
\text { leaves }\end{array}$} & II & 1.00 & & & & & & \multirow{6}{*}{$\begin{array}{c}\% \text { of } \\
\text { germination }\end{array}$} & 0.13 & & & & & \\
\hline & III & 1.00 & 1.00 & & & & & & 0.05 & 1.00 & & & & \\
\hline & IV & 1.00 & 1.00 & 1.00 & & & & & 0.00 & 1.00 & 1.00 & & & \\
\hline & $\mathrm{V}$ & 1.00 & 0.23 & 1.00 & 1.00 & & & & 0.05 & 1.00 & 1.00 & 1.00 & & \\
\hline & VI & 0.15 & 0.00 & 0.03 & 0.06 & 0.19 & & & 0.00 & 0.15 & 0.29 & 1.00 & 0.94 & \\
\hline & VII & 1.00 & 0.11 & 1.00 & 1.00 & 1.00 & 1.00 & & 0.01 & 0.96 & 1.00 & 1.00 & 1.00 & 1.00 \\
\hline
\end{tabular}

\section{Discussion}

During plant domestication, genotypes with larger seeds were selected for their contribution to increased grain yield, as well as for their positive effect on the quality of end-use products [10]. In our study, a significant correlation between seed size, seedling development (plantlet height and stem diameter) and emergence rate was observed for the pecan cultivar Importada. Seeds with the larger mass (Classes VI and VII, heavier than $9.0 \mathrm{~g}$ ) produced larger seedlings and revealed higher emergence rates.

For commercial orchards, the heritability of these traits is an important factor. Thus, the genetic control of the variable determining the desired traits is vital. The control of seed size has been 
recognized as a complex trait and attributed to both genetic and epigenetic pathways. Based mainly on studies from cultivated cereal crops, new information is constantly added to the accumulated knowledge about this issue. For example, a study using high-throughput sequencing identified twenty-two microRNAs related to seed size in the shrub plant Hippophae rhamnoides [11], generating data which support future studies on genetic transformation.

The genetic control of seed size and yield in woody plants, on the other hand, has been investigated less. Recently, a homolog of Auxin Response Factor 19 controlling seed size and seed yield was identified in Jatropha curcas, demonstrating the importance of the auxin pathway in seed size and yield control in woody plants [12]. Indeed, the transgenically-mediated overexpression of this gene in J. curcas and in Arabidopsis thaliana significantly increased seed size and seed yield in these plants [12].

Despite the limited knowledge about specific topics concerning the genetic control of seed size in woody plants, intraspecific variation in this trait is common in tree species. Evidence of a positive association between seed mass and mean time to germination was observed by Norden et al. [13] in an analysis of 1037 tropical tree species. Bispo et al. [6] reported direct interference of seed size in seedling development of Anadenanthera colubrina, with larger seeds yielding higher growth. Evaluating the capacity of seed fragments of Eugenia pyriformis to produce new seedlings, Pratavieira et al. [14] observed a significantly higher capacity by larger seeds. However, Moles and Westoby [15] found no relationship between seed mass and survival through the transition from seed to emerged seedlings in populations of 33 species growing under natural conditions. Jijeesh and Sudhakara [16] reported a lack of correlation between drupe size and the number of leaves, while the analysis of variance indicated that seedling height, collar diameter, leaf area, tap root length and number of lateral roots were significantly influenced by drupe size in Tectona grandis with larger drupes recording the highest seedling attributes.

Such positive correlations have been used as indicative of physiological quality, justifying the use of size classes for seed selection. In cork oak (Quercus suber), the largest seeds were correlated with plantlet survival in dry periods, suggesting the need for selection for this trait across sites experiencing drought [17]. The high positive correlation $(r>0.81)$ between seed mass, emergence rate and seedling development revealed in our study may be related to the selection procedures performed by the nurserymen. Selecting plus-trees for morphological characters leads to the 'hitchhiking' of some genes related to the desired traits. In cereal crops, seed size is a characteristic domestication attribute, and cultivated inbred lines and landraces usually have larger seeds than their wild progenitors. Accordingly, a signature of selection during domestication was observed in 63 out of 114 genes putatively related to seed size in Sorghum bicolor [10].

Different from the wild trees studied by Adams and Thielges [7], the pecan cultivar Importada has been selected for generations for traits such as nut size, tree development and adaptability to the subtropical climatic conditions of Southern Brazil. The seedlot of pecan used in this study may also express the effect of a genetic stratification of seed parents [18] because seeds were obtained from mother-trees cultivated with the aim of producing nuts for the food industry. Since these mother-trees were obtained from commercial nurseries, they were previously selected during seedling production.

\section{Conclusions}

Our study revealed a positive correlation between seed mass, seedling emergence and plantlet vigor, suggesting that seed mass can be used as a direct method for seed selection towards production of healthy pecan seedlings. However, in addition to superior emergence rate and seedling development, orchards should produce seeds with high breeding values and high gene diversity. Therefore, controlled studies-taking into consideration the recalcitrant nature of pecan seeds [19] and the influence of genetic stratification of seed parents on these traits-should be carried out. In addition, an increase in seed mass is usually associated with a decrease in the number of seeds that a plant can produce per unit canopy per year [20]. Thus, long-duration studies are recommended in order to evaluate this aspect. Furthermore, as suggested by Thompson and Conner [1], we are performing an 
update of the current genetic status of this crop with genomic characterization of the cultivars planted in subtropical regions, since breeding objectives have become more refined, and available methods of genetic plant improvement have expanded.

Author Contributions: Conceptualization, T.P. and I.P.; methodology, T.P.; formal analysis, T.P. and V.M.S.; resources, M.F.B.M.; writing — original draft preparation, T.P.; writing - review and editing, V.M.S.; supervision, M.F.B.M.; project administration, M.F.B.M.; funding acquisition, M.F.B.M. and V.M.S.

Funding: This research was funded by Conselho Nacional de Desenvolvimento Científico e Tecnológico (CNPq), Process 442995/2014-8.

Acknowledgments: Authors thank to Conselho Nacional de Desenvolvimento Científico e Tecnológico (CNPq) for fellowships to M.F.B.M. and V.M.S., and to Fundação de Amparo à Pesquisa do Estado do Rio Grande do Sul (FAPERGS) for the scholarship to T.P.

Conflicts of Interest: The authors declare no conflicts of interest.

\section{References}

1. Thompson, T.E.; Conner, P.J. Pecan. In Fruit Breeding; Badenes, M.L., Byrne, D.H., Eds.; Springer: New York, NY, USA, 2012; Volume 8, pp. 771-801, ISBN 978-1-4419-0762-2.

2. Zhang, R.; Peng, F.; Li, Y. Pecan production in China. Sci. Hortic. 2015, 197, 719-727. [CrossRef]

3. Cargnelutti Filho, A.; Poletto, T.; Muniz, M.F.B.; Baggiotto, C.; Poletto, I.; Fronza, D. Sampling design for height and diameter evaluation of pecan seedlings. Ciênc. Rural 2014, 44, 2151-2156. [CrossRef]

4. Poletto, I.; Muniz, M.F.B.; Poletto, T.; Stefenon, V.M.; Baggiotto, C.; Ceconi, D.E. Germination and development of pecan cultivar seedlings by seed stratification. Pesqui. Agropecu. Bras. 2015, 50, 1232-1235. [CrossRef]

5. Pereira, W.A.; Pereira, S.M.A.; Dias, D.C.F.S. Influence of seed size and water restriction on germination of soybean seeds and on early development of seedlings. J. Seed Sci. 2013, 35, 316-322. [CrossRef]

6. Bispo, J.S.; Costa, D.C.C.; Gomes, S.E.V.; Oliveira, G.M.; Matias, J.R.; Ribeiro, R.C.; Dantas, B.F. Size and vigor of Anadenanthera colubrina (Vell.) Brenan seeds harvested in Caatinga areas. J. Seed Sci. 2017, 39, 363-373. [CrossRef]

7. Adams, J.C.; Thielges, B.A. Seed sizes effects on first-and second-year pecan and hybrid Pecan growth. Tree Planters' Notes 1979, 30, 31-33.

8. Hammer, Ø.; Harper, D.T.; Ryan, P.D. Past: Paleontological Statistics Software Package for Education and Data Analysis. Palaeontol. Electron. 2001, 4, 1-4.

9. Wessa, P. Pearson Correlation (v1.0.13) in Free Statistics Software (v1.2.1), Office for Research Development and Education. 2017. Available online: https://www.wessa.net/rwasp_correlation.wasp/ (accessed on 5 March 2018).

10. Tao, Y.; Mace, E.S.; Tai, S.; Cruickshank, A.; Campbell, B.C.; Zhao, X.; Van Oosterom, E.J.; Godwin, I.D.; Botella, J.R.; Jordan, D.R. Whole-Genome Analysis of Candidate genes Associated with Seed Size and Weight in Sorghum bicolor Reveals Signatures of Artificial Selection and Insights into Parallel Domestication in Cereal Crops. Front. Plant Sci. 2017, 8, 1237. [CrossRef] [PubMed]

11. Ding, J.; Ruan, C.; Guan, Y.; Krishna, P. Identification of microRNAs involved in lipid biosynthesis and seed size in developing sea buckthorn seeds using high throughput sequencing. Sci. Rep. 2018, 8, 4022. [CrossRef] [PubMed]

12. Sun, Y.; Wang, C.; Wang, N.; Jiang, X.; Mao, H.; Zhu, C.; Wen, F.; Wang, F.; Lu, Z.; Yue, G.; et al. Manipulation of Auxin Response Factor 19 affects seed size in the woody perennial Jatropha curcas. Sci. Rep. 2017, 7, 40844. [CrossRef] [PubMed]

13. Norden, N.; Daws, M.I.; Antoine, C.; Gonzales, M.A.; Garwood, N.C.; Chave, J. The relationship between seed mass and mean time to germination for 1037 tree species across five tropical forests. Funct. Ecol. 2009, 23, 203-210. [CrossRef]

14. Prataviera, J.S.; Lamarca, E.V.; Teixeira, C.C.; Barbedo, C.J. The germination success of the cut seeds of Eugenia pyriformis depends on their size and origin. J. Seed Sci. 2017, 37, 47-54. [CrossRef]

15. Moles, A.T.; Westoby, M. Seedling survival and seed size: A synthesis of the literature. J. Ecol. 2004, 92, 372-383. [CrossRef] 
16. Jijeesh, C.M.; Sudhakara, K. Larger drupe size and earlier geminants for better seedling attributes of teak (Tectona grandis Linn. f.). Ann. For. Res. 2013, 56, 307-316.

17. Ramírez-Valiente, J.A.; Valladares, F.; Gil, L.; Aranda, G. Population differences in juvenile survival under increasing drought are mediated by seed size in cork oak (Quercus suber L.). For. Ecol. Manag. 2009, 257, 1676-1683. [CrossRef]

18. Chaisurisri, K.; Edwards, D.G.W.; El-Kassaby, Y.A. Effects of seed size on seedling attributes in Sitka spruce. New For. 1994, 8, 81-87. [CrossRef]

19. Dalkiliç, Z. Effects of drying on germination rate of pecan seeds. J. Food Agric. Environ. 2013, 11, 879-882. [CrossRef]

20. Henery, M.L.; Westoby, M. Seed mass and seed nutrient content as predictors of seed output variation between species. Oikos 2001, 92, 479-490. [CrossRef]

(C) 2018 by the authors. Licensee MDPI, Basel, Switzerland. This article is an open access article distributed under the terms and conditions of the Creative Commons Attribution (CC BY) license (http:/ / creativecommons.org/licenses/by/4.0/). 